\title{
Magyarországi helyzetkép táplálkozási szokásokról a kultúra és a hagyományok tükrében, különös tekintettel a romákra
}

\section{Overview of eating habits in Hungary based on cultural traditions focused especially on the Roma population}

\author{
Kocsis Éva doktoranda, Mózes Noémi doktoranda, habil. Feith Helga PhD \\ Semmelweis Egyetem Egészségtudományi Kar- Társadalomtudományi Tanszék \\ evakocsis66@gmail.com,noni900831@gmail.com,feith@se-etk.hu
}

Initially submitted Febr 27

\begin{abstract}
For centuries, the traditional eating habits of the Hungarian people have also been influenced by historical events, what kind of rule we were under, or which country we were allied with. The eating habits of the smaller segments, such as families, were determined by the given political situation and social affiliation. Of course, the weather conditions also had a great influence on the ingredients of the kitchen. Today's modern eating habits are influenced by knowledge, financial means, fashion, the environment. The combination of these, combined with physical inactivity, causes the domestic population to be a leader in the world and European rankings in terms of overweight and obesity. The health situation of the Roma, as the largest minority in Europe, is of great importance in Hungary as well. Their health is worse than that of the majority of society, and their life expectancy is lower. The ethnic group with a long tradition and customs, preserving the ancient heritage proudly. In addition to their disadvantaged situation, this still affects their eating habits today. Despite the abandonment of the nomadic lifestyle, typical flavours and kitchen techniques are still used today, despite the fact that assimilation greatly influences their diet. Going through the history of both the Hungarian and the Gypsy minority, we review eating habits, what they have preserved from the past, and the extent to which the fashion of the "Western way of life" has an impact on the eating habits of modern society.
\end{abstract}

Keywords: nutrition, Roma, traditions, Hungarian, food

Kulcsszavak: táplálkozás, roma, magyar, hagyományok, ételek

Keywords: nutrition, Roma, traditions, Hungarian, food

\section{Az étel}

Az érzékszerveink szerint az étel nem csupán energiaforrás, hanem élvezeti forrás is. Az ételek étrendbeli szerepe az adott történelmi kor és társadalmi csoportok ételekhez füződő érzelmeit, lehetőségeit is megjeleníti, pl. ünnepek alkalmával, a különféle hétköznapi szokások mentén tálalt ételek vagy akár az ínséges időkben az alapvető élelmiszereket helyettesítő fogások. Itt említhetjük példaként a böjthöz füződö tiltásokat is. (Báti 2019:63-77) ezt a mondatot át kellene fogalmazni! 
Kaleidoscope

\section{Általános helyzetkép napjainkban}

Az Egészségügyi Világszervezet (WHO) adatai rámutatnak arra, hogy a világon évről évre egyre emelkedik a túlsúlyosak, elhízottak aránya. 1975 óta világszerte az elhízás előfordulási gyakorisága a háromszorosára nőtt. Az elhízás mértéke világszerte csaknem megduplázódott 1980 és 2008 között. A 2008-jelentések szerint a WHO európai régiójában a férfiak és a nők több mint $50 \%$-a volt túlsúlyos, a nök 23\% -a és a férfiak 20\% -a pedig elhízott. A 2016-os felmérések alapján a teljes felnőtt lakosság 39\% -a volt túlsúlyos, 13\%-a pedig elhízott. (WHO 2019) A WHO adatai szerint az Európai lakosság esetében még rosszabb a helyzet, hisz a népesség 50\%-a túlsúlyos vagy elhízott kategóriába sorolható. (WHO 2019) Össze kellene hasonlítani egy régebbi adattal, akkor lenne látható az előbb említett emelkedés.

Hazánkban a 2014-ben készült Országos Táplálkozás és Tápláltsági Állapot Vizsgálat (OTÁP 2014) eredményei alapján hazánk lakosságának 2/3-a túlsúlyos vagy elhízott és az életkor előrehaladtával nő a BMI átlag. A magyarok jelentős súlytöbblete az egészségtelen táplálkozásra és a fizikai aktivitás hiányára vezethető vissza. Hazánk lakosságának étkezésére jellemző a túlzott mennyiségü állati eredetü zsiradék, kevés a teljes kiörlésű gabonából készült élelmiszer, illetve a zöldség és gyümölcsök fogyasztása. Átlagosan 5 órát ülünk és csak 7000 lépést teszünk meg naponta, ami az ajánlott 10.000 lépéshez képest kevés. (OTÁP 2014)

Hazánk lakosságának táplálkozási szokásait az elmúlt években több kutatás is vizsgálta, amelyek egyértelmüen rámutatnak arra, hogy a fiatalabb (egyetemista) korosztályban a nemek között nincs lényeges eltérés a zöldség és gyümölcsfogyasztás tekintetében. A vizsgált 266 fiatalok (45\% nő, 55\% férfi) 20,6\%-a naponta fogyaszt gyümölcsöt, míg a napi zöldség fogyasztás csak 17,3\%-os arányú. (Koroknai-Pfau 2020:18-29) Egy másik, átfogóbb vizsgálat korcsoportokra bontva mérte fel a hazai lakosság táplálkozási szokásait, amely szerint a többség $(82,3 \%)$ naponta fogyaszt zöldséget és gyümölcsöt, kisebb százalék hetente $(15,5 \%)$ vagy csak havonta $(1,8 \%)$. Ezen élelmiszerek rendszeres napi fogyasztása inkább a nőkre jellemző, mint a férfiakra. Édességet naponta 40,0\% eszik, 45,5\%-uk hetente, a többi válaszadó ennél ritkábban fogyaszt édességet (12,7\%), illetve akik sosem esznek édességet, ők csak a minta 1,8\%-át képviselik.

Energiaitalt a többség $(62,3 \%)$ sosem iszik, vagy csak nagyon ritkán $(22,7 \%)$. Koffein tartalmú frissítőt havonta 5,5\% fogyaszt, ennél ritkábban (hetente) 5,9\%-uk, ugyanakkor 3,6\%-uk napi rendszerességgel. Általánosságban a napi étkezések száma a többség esetében négyszeri volt, illetve hasonló arányban voltak, akik háromszor esznek a nap folyamán. Kevés volt azon válaszadók száma, akik napi ötször vagy akár többször is étkeznek, ahogyan kevesen voltak azok is, akik napi 2 alkalommal vagy kevesebbszer vesznek magukhoz ételt. (Dinnyés-Pusztafalvi-Tarkó 2019:36-63)

A húsfogyasztási szokások kapcsán megoszlik a népesség véleménye, vannak húsimádók és természetesen vannak, akik sosem esznek állati eredetü élelmiszereket. A méréskelten húskedvelö lakosság inkább a fehér húsokat, ezen belül is inkább a szárnyasokat választja, míg a húsimádók, akik napi húsfogyasztók, egyformán kedvelik a vörös és fehér húsokat is. Akik csak ritkán fogyasztanak húsfélét, ők inkább a halakat választják, ezt követi a csirke, a marha és a sertés. (Keller-Dernóczy-Huszka 2017:19-24)

http://www.kaleidoscopehistory.hu 
Kaleidoscope

\section{Roma ${ }^{1}$ kutatások adatai}

Európában a romák képezik a legnagyobb etnikai csoportot. Számuk becslések szerint 10-12 millióra tehető, ebből kb. 6 millióan állampolgárok vagy az EU lakói, a többiek pedig az EU-n kívüli országokból érkeztek és tartózkodnak az Unió területén. (Europien Comission 2020) Iskolázottság, egészségi állapot, jövedelem, várható élettartam tekintetében jóval alulmaradnak mind az EU, mind a saját országukon belüli átlagtól, ugyanakkor a teljes népességen belüli arányuk, lélekszámuk emelkedik. A 2011-es népszámlálási adatok szerint Magyarországon közel 316 ezer fő vallotta magát roma származásúnak. Azonban a magyar kutatások alapján számuk eléri a 867 ezer föt. (PÁSZTOR-Pénzes-Tátrai 2016: 5-21) A roma kisebbség korfája jelentősen fiatalabb összetételt mutat, mint a többségi társadalomé. (KSH 2011) Az is igazolt tény, hogy a fiatal korfa ellenére a romák egészségi állapota még mindig rosszabb a többségi társadalom tagjainak egészségi állapotához képest, ráadásul a romák születéskor várható élettartama 10-15 évvel kevesebb. Hazánk egyik legsérülékenyebb csoportja, a roma lakosság korai halálozási okainak hátterében főként a rossz egészségmagatartás áll. Sajnos föként szegregáltan és telepszerüen élő romák nagy százaléka (40\%) nem is gondolja úgy, hogy tehetne bármit is az egészsége javítása érdekében. (Ádány 2008:16). Egy interjúkon alapuló kutatás szerint a cigányok magyarázata a korai mortalitásukra az volt, hogy az alapvető emberi jogaik sérülnek, ezért élnek többségében a létminimum alatt, hiszen nincs munkájuk, ebből eredően pedig a szociális és egészségügyi szükségleteik sincsenek kielégítve. (Vajda 2001:3147-3150)

A romák egészségi állapotáról több felmérés is készült, de tudomásunk szerint a táplálkozási szokásaikról átfogó kutatás jóval kevesebb felmérés készült. Leginkább a szegregáltan élő romák tápláltsági állapotáról rendelkezünk adatokkal.

2010-ben egy egészségfelmérés adatai szerint a résztvevő 18-29 éves roma nők 10\%-a sovány, 71\%-a normál testsúlyú, 14\%-a túlsúlyos és 4\%-a elhízott volt. Zöldséget és gyümölcsöt naponta 32\%-uk, hetente 49\%-uk, ennél ritkábban 18\%-uk fogyasztott. A 30-44 éves korosztályban már csak 8\% volt sovány, $52 \%$ normál súlyú, míg a túlsúlyosak aránya $28 \%$-ra nőtt, elhízott pedig $11 \%$-uk volt. Naponta zöldséget és gyümölcsöt ez a korcsoport 36\%-a fogyasztott, míg hetente 45\%-uk, és ennél ritkábban 19\%-uk. A 45-65 éves korosztály vonatkozásában $4 \%$ volt sovány, $41 \%$ normál, $34 \%$ túlsúlyos és $21 \%$ elhízott. Naponta $36 \%$-uk, hetente $42 \%$-uk és ennél ritkábban $18 \%$-uk evett zöldséget és gyümölcsöt. A férfiak esetében a 18 29 éves korosztály 0,5\%-a volt sovány, 58\%-a normál, 37\%-a túlsúlyos és 5\%-a elhízott. Naponta 28\%-uk, hetente 44\%-uk és ennél ritkábban 27\%-uk evett zöldséget és gyümölcsöt. A 30-44 éves férfiak között 3\% volt sovány, $39 \%$ normál, $40 \%$ túlsúlyos és $18 \%$ elhízott. Zöldség- és gyümölcsfogyasztás tekintetében naponta $31 \%$, hetente $45 \%$ és ennél ritkábban pedig $24 \%$ fogyasztott ilyen jellegü vitamin tartalmú élelmiszert. A 45-65 éves férfiak körében csupán 1\% volt sovány, 41\% normál, 36\% túlsúlyos és 22\%-uk pedig elhízott. A napi zöldség- és gyümölcsfogyasztás csak 37\%-ra volt jellemző, 31\%-uk hetente, 32\%-uk ennél is ritkábban fogyasztott zöldségeket vagy gyümölcsöket. (Csépe 2010:96-98) A fenti eredményekből jól látható, hogy a felmérésben résztvevő romák körében mindkét nemben az életkor elöre haladtával csökkent a soványok aránya, miközben nőtt a túlsúlyosak és elhízottak aránya (1. ábra).

\footnotetext{
${ }^{1}$ 1971-ben Londonban megtartott, első Roma Világkongresszuson a résztvevők konszenzussal fogadták el, hogy a világ összes cigány származású emberének közös és egyben hivatalos elnevezése a roma. A cikkben is következetesen használjuk a roma elnevezést.
} 
Kaleidoscope

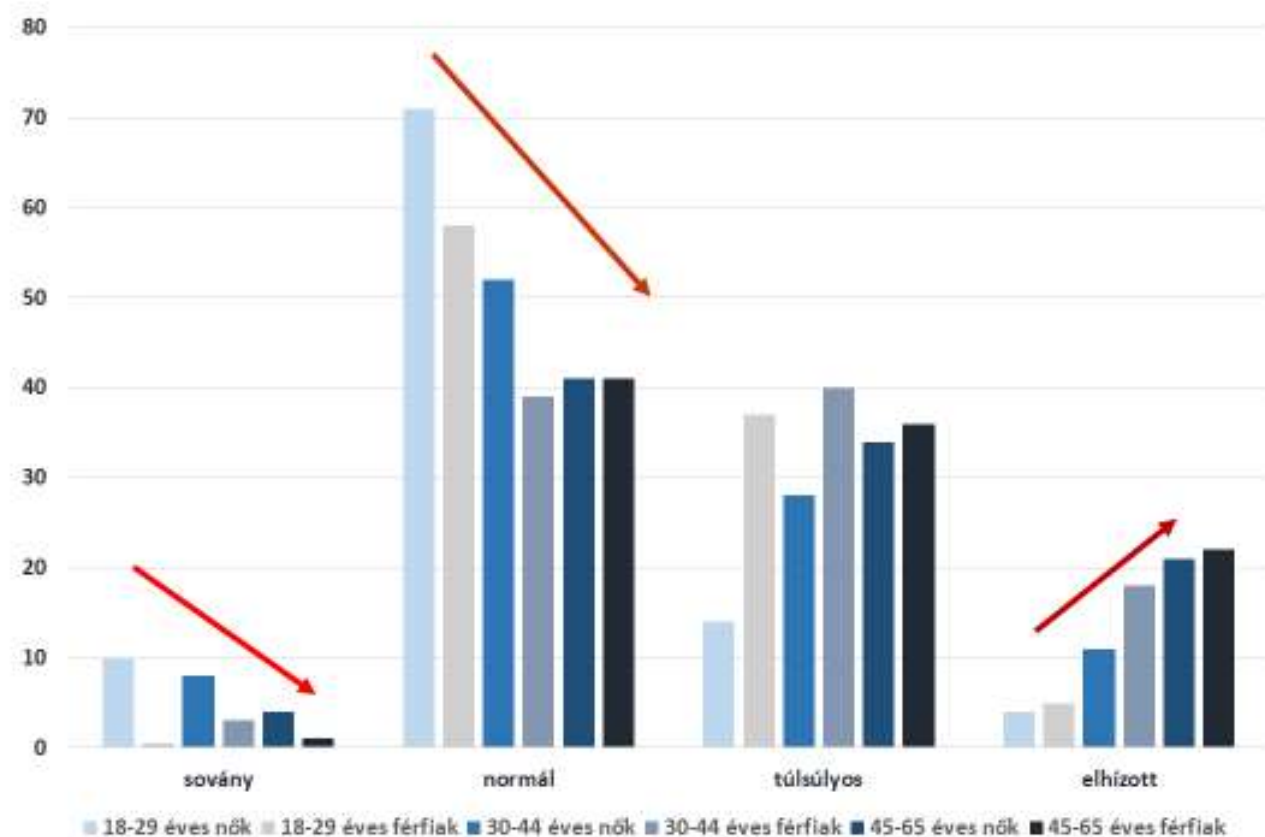

1. ábra Roma populáció testsúly kategória besorolásának változása az életkor szerint (\%)

Forrás: saját szerkesztés, Csépe Péter 2010-es kutatásának adatai alapján (Csépe 2010: 96-98)

Egy másik, frissebb, Észak-Kelet Magyarországon, telepszerüen élő romák körében végzett vizsgálat is megerősítette az előző kutatás eredményeit. Eszerint az elmúlt évekhez képest nőtt az elhízás mértéke, hiszen a 18-29 éves korosztályban 4\%-ról 27\%-ra, a roma férfiak esetében pedig ez az arány 5\%-ról 24\%ra emelkedett. A nem roma népeség esetében ilyen mérvü emelkedést csak a 45-65 éves férfiak korosztályában lehetett tapasztalni. A napi zöldség- és gyümölcsfogyasztás a romák körében ritkább, mint az általános népesség körében, különösen igaz ez a roma férfiakra. Miközben általánosságban azt tapasztalták, hogy nőtt hazánkban a zöldség- és gyümölcsfélék fogyasztási gyakorisága. (Ádány-Sándor 2019: 1596-1611)

A hazai romák $60 \%$-a él mélyszegénységben. Az alultápláltság is körükben jellemző inkább, az ÁNTSZ adatai alapján a hazai férfi lakosság 4,1\%-a, a nők 8,7\%-a alultáplált. A Kethanipe 2007-es adatai alapján a cigány férfiak 10,3\%-a, a cigány nők 22,1\%-a nem éri el a WHO által ajánlott normál BMI értéket. Rendszertelen, alacsony energiatartalmú ételek fogyasztása mellett az ún. ínségételek is jelen vannak esetükben. A gazdag cigányoknál az elhízás egyenlő a jómóddal. Hús minden nap van az asztalon, azonban gyümölcs, fözelék, tejtermék, sajt ritkán kerül kínálásra. A jómódú családok asztaláról továbbra sem hiányozhat a „nemzeti” ételük, az ún. töltött és húsos káposzta, ahogyan az ún. punya/vakaro/bolyi sem. Bár a gazdagok ételei ízletesek, de közel sem egészségesek. Ehhez még hozzáadódik a mozgásszegény életmódjuk is, így ennek köszönhetően az elhízás sem ismeretlen jelenség náluk. A súlyosan elhízott hazai férfiak aránya $1,0 \%$, a nőké $1,6 \%$, míg a cigány férfiaknál $2,1 \%$ és a nőknél 2,4\% ez az arány a Kethanipe 2007-es adatai alapján. (Kármán 2018:31-32) 
Kaleidoscope

Egy 2013-2014-ben készült felmérés 110 roma fiatalt kérdezett meg táplálkozási szokásaikról. A vizsgálat szerint a naponta reggelizö gyermekek nagyobb arányban fordultak elö a megkérdezett roma fiatalok között, mint az összehasonlítás alapját képező HBSC vizsgálatban megkérdezett hazai fiatalok között. A gyermekek napi étkezésének száma és a családok anyagi helyzete között nem találtak összefüggést, ahogyan a gyorséttermek látogatási gyakoriságát sem befolyásolta a család jövedelmi helyzete. Azonban a vizsgálat rámutatott arra is, hogy az alacsonyabb iskolázottságú anyák gyermekei fogyasztottak rendszeresen a gyorséttermek kínálatából. A napi zöldség és gyümölcs fogyasztás a vizsgált roma fiatalok körében nagyobb arányban fordult elő, mint a hazai fiatalokat vizsgáló HBSC kutatás esetében. A vizsgált mintában az alacsonyabb iskolázottságú roma anyák gyermekei télen kevesebb, míg nyáron több gyümölcsöt fogyasztottak, mint a magasabb iskolai végzettséggel rendelkező anyák gyermekei. Ez a tény már tükrözi az egészséges táplálkozás összefüggéseit a jövedelmi helyzetükkel, illetve a szülök iskolázottságával. Alátámasztotta ezt a megállapítást az is, hogy a magasabb iskolázottságú anyák gyermekei nagyobb arányban inkább baromfi, kisebb arányban disznóhúst fogyasztottak, ahogyan ők inkább barna, mint fehér kenyeret adtak gyermekeiknek. A magasabb iskolázottságú szülök gyermeki több tejterméket is fogyasztottak. A vizsgált roma fiatalokra egyértelmüen jellemző volt az üres kalóriák bevitele, hiszen $60 \%$ uk naponta, 82\%-uk hetente élvezte az édes ízeket, ami jóval magasabb aránynak bizonyult, mint az országos átlag. Cukros üdítővel a roma fiatalok $62 \%$-a oltotta naponta szomját és csak $29 \%$-uk ivott vizet, ha szomjas volt. A 110 megkérdezett fiatal között csupán 3 gyermek jelezte, hogy sosem ivott energiaitalt, a többi 107 ifjú kisebb-nagyobb rendszerességgel fogyasztotta az egészségtelen élénkítő italt. Az energiaital fogyasztási eredmények hasonlóak voltak egy másik hasonló témájú kutatás eredményeihez (BekénéKovácsné 2008: 174-179). (Kocsis-Angyal 2015:231-245)

Egy 2019. évi roma felmérés adatai szerint a 18-35 éves korosztályban a férfiak 50,8\%-a, a nők 40,6\%-a túlsúlyos vagy elhízott. A 35-64 évesek között pedig a férfiak 58,3\%-a, a nők 56,7\%-a küzd súlyfelesleggel. Ezeket az adatokat úgy is értelmezhetjük, hogy minden második roma férfi és minden harmadik roma nő súlyfelesleggel él, vagyis általánosságban a roma felnőttek 20\%-át érinti az elhízás problémája, ami egyre nagyobb terheket fog róni a roma családokra és a társadalomra az elhízáshoz kapcsolódó társbetegségek miatt. (Kiss-Andó-Fritz-Lakner 2019:1097-1104)

\section{Táplálkozási szokások a régmúltban és napjainkban}

A fentebb ismertetett adatok tükrében tekintsünk vissza Magyarország táplálkozási szokásaira, kulturális hagyományaira. A magyar nép étkezési szokásait, kultúráját, a magyar konyha alakulását is meghatározta a történelem. A honfoglalás előtt őseink halásztak, vadásztak, gyüjtögettek, sütöttek és föztek, de ismerték az aszalást, szárítást és a füstölést is. Leginkább kedvelt hús a marha, birka, kecske volt, de szívesen fogyasztották a szárnyasokat is, ahogyan a tej és tejtermékeket is. A konyhájuk edényzetének fejlődésével együtt kedvelték meg a levesféléket, a tartalmas ragukat, amelybe a zöldségek széles választéka is helyet kapott. A Kárpát medencébe érve az éghajlat kedvező feltételeket biztosított számukra a letelepedésre, és ezzel együtt az állattenyésztés és növénytermesztés kiterjesztése változást hozott a táplálkozási szokásaikban. Ekkor honosodott meg a magyar nép körében a gabona, és a tésztaféleségek fogyasztása. Szent István uralkodása idején újabb változás következett, hiszen beépültek a német és a görög konyha ételei is a táplálkozásba. A XV. században a káposzta nagyon fontos élelmiszerré vált népünk számára, majd Mátyás uralkodása idején az itáliai ízek is terítékre kerültek, ekkor kóstolták először őseink a sajtokat, déli gyümölcsöket és az egzotikus füszereket. A húsok között gyakran szerepelt a marha, a sertés, kedveltté vált a pulyka és a liba, de szívesen fogyasztották a vadhúsokat is. Ekkor vezették be a kovászos kenyeret is az 
étrendbe, illetve a hagyma és a fokhagyma is kedveltté vált ebben az időszakban. A XVI. században az erdélyi konyhának köszönhetjük a paprikát, paradicsomot, burgonyát, vagy a mézet. A törökök ismertették meg velünk a kukoricát, a dohányt. A XVII-XVIII. században terjedt el a zsírban sütés és fözés, a levesek sokfélesége, de ekkor vonult be a csokoládé, a vaj, a tükörtojás az étrendünkbe. A XIX. században már számos utazó számolt be a paprikáscsirkéröl, vagy a gulyásról. Az osztrák hatásnak köszönhetjük a francia konyha hódításait, amelyek azonban inkább az éttermek, vagy a gazdagabb családok asztalán jelent meg, a szegények körében kevéssé volt ismert (például az omlett). Ugyanakkor számos, világszerte ismert magyar ételünket híres magyar emberekről nevezték el, így például a Jókai bablevest, az Eszterházy rostélyost, a Rigó Jancsit, a Dobos tortát, a Zserbó szeletet, a Gundel palacsintát, vagy akár a Rákóczi túróst. (A magyar gasztronómia története 2010)

A XX. századot megelőzően tehát a szívesebben fogyasztott ételek és italok teljes mértékben kifejezték az egyének társadalmi hovatartozását, illetve Magyarország geopolitikai helyzetéből adódóan az éppen aktuális társadalompolitikai, nemzetközi értelemben vett kapcsolati rendszerét.

Ma már a modern fogyasztói társadalomban élünk, ahol az extrém élelmiszerek is helyet kapnak. Hazánkban is sokan követik a trendeket, mint a „fast food”, a „street food” világát, de a „bio”, vagy a „mentes élelmiszerek" széles választékát is megtaláljuk. A modern élelmiszerfogyasztási szokások kapcsán nem hagyhatjuk figyelmen kívül a társadalom korösszetételét sem, hiszen a fiatalok mellett, a nyugdíjasok is egy külön csoportot képviselnek társadalmunkban, az ő fogyasztási szokásaik is sajátosak a maguk nemében. Utóbbiaktól a trendek távol állnak, aki megteheti, inkább a maga kis konyhakertjében megtermelt alapanyagokból, a naponta maga fözte ételeket kedveli.

Emellett a társadalmi rétegek fogyasztási szokásai napjainkban is mutatnak további különbségeket, hiszen a szegénységben élők többsége rendszertelenül étkezik, az egészséges ételek nem fontosak számukra, sokszor azért sem, mert az anyagi korlátokon kívül az alapvető ismereteik is olykor hiányoznak. A közép és felsőbb társadalmi rétegekhez tartozó iskolázottabb egyének inkább az egészséges, drágább, de minőségi alapanyagokból készült ételeket preferálják. Mindezek mellett a hazai szokásokban vezető helyet foglalnak el a levesek, a burgonya, a tészta, a sertéshús és a szárnyasok. Az üdítők is nagy teret hódítanak, továbbra is mentes vagy szénsavas változatukban. (Kozák 2009:19-23)

Egy 2017-es 400 föt vizsgáló felmérés szerint az étkezések gyakorisága nincs összefüggésben az anyagi helyzettel, az átlagosnál gyakrabban fordult elö, hogy a magasabb jövedelmek csak napi 2 alkalommal étkeztek. Egyébként a hazai lakosság a napi három étkezést preferálja továbbra is. A reggelit sokan kihagyják, az ebéd inkább a fóétkezés, de minden negyedik magyar szerint ez inkább a vacsora. A megkérdezett családok felében (41\%) sem föznek rendszeresen, de egyébként a megkérdezettek 54\%-a visz magával ebédet otthonról, 17\%-uk a menzán, 5\%-uk egy közeli kifőzdében ebédel. 21\%-uk azonban csak este otthon eszi meg asz ebédjét. Naponta a vizsgált személyek harmada fogyaszt tejterméket, negyede húst és zöldséget és csak 17\%-uk eszik minden nap gyümölcsöt. A húsfélék között a baromfi a legkedveltebb (67\%), majd a sertés (30\%) következik, és halat csak 1\% eszik rendszeresen. (NLC.GASTRO 2017)

A 2019-es Európai Lakossági Felmérés (ELEF 2019) adatai alapján a hazai lakosság 55\%-a naponta, 35\%a hetente, míg 9,4\%-a ritkábban vagy sosem fogyaszt gyümölcsöt. Zöldséget valamivel kevesebben, $45 \%$ fogyaszt naponta, $46 \%$-uk hetente és $8,8 \%$ pedig ennél is ritkábban vagy sosem. A fogyasztás gyakoriságát a jövedelem befolyásolja, bár a legmagasabb kategóriákba tartozó egyének nem rendszeres fogyasztók, míg az iskolázottság kapcsán nincs jelentős eltérés a napi zöldség és gyümölcsfogyasztás tekintetében. Napjainkban egyre többen követnek valamilyen speciális diétát, legtöbben diabetikus, laktózmentes, sószegény, energiaszegény, gluténmentes, tejmentes és végül vegán diétát követnek. A diéták alkalmazási 
Kaleidoscope

gyakorisága az életkor elörehaladtával növekszik. A húsfélék tekintetében a lakosság 30\%-a naponta elfogyaszt valamilyen húskészítményt, negyede inkább fehérhúsokat kedvel, míg 13\%-ban a vörös húsfélék kerülnek az asztalra. A tengeri halakat és gyümölcsöket továbbra sem kedveli a hazai lakosság. (KSH 2019) Egy 2020-as cikk pedig felhívja a figyelmet arra, hogy hazánkban is egy nagyobb teret hódít az egészségtudatosság, hogy az egészségünkért mi magunk is sokat tehetünk. Ennek egyik fontos szegmense a táplálkozás. A táplálkozásban, az élelmiszerek vásárlása során a tudatosság manapság nemcsak trendi, hanem trenddé válik, hiszen a magyarok közel fele követ valamilyen diétát, változtat az étkezési szokásain. Megjelent a „szuperélelmiszer” vagy „,szuperétel” fogalma, ami azt jelenti, hogy az a bizonyos zöldség vagy gyümölcs a tápanyagösszetétele révén egészségügyi előnyhöz juttatja fogyasztóját. Ezek az élelmiszerek a köztudatban megelőzik a betegségek kialakulását, lelassítják az öregedést, de növelhetik akár az erőnlétünket vagy az intelligenciánkat is. Hazánkban továbbra is hódít a vegán étkezés, a teák egyre nagyobb népszerüségnek örvendenek, de divatosak lettek az alkoholmentes koktélok is. Egyre többen fogyasztják a növényi eredetü fehérjéket, mint a tofut (szója), de a füszerekröl sem szabad megfeledkezni, mint a kurkuma, fokhagyma. A levesek kultúrája is egyre inkább terjed, de a prebiotikumokat is tudatosan esszük meg egészségünk érdekében. A chia mag napjainkban hazánkban is csúcsokat dönt a kedveltségi listán, de egyre többen készítik el a batátát (édesburgonya) vagy akár a lila burgonyát is. (MDOSZ 2018)

2021-ben pedig a pandémiának köszönhetően az egészség fontosságának fényében elötérbe kerülnek az alternatív gyógymódok, így a gyógynövények, mint a bodza, kurkuma, gyömbér. A táplálékok terén előtérbe helyezik a tápanyagokban gazdag élelmiszereket, melyek a mentális egészséget, az alvásminőséget javítják, vagy a stresszt csökkentik. Hangsúlyt kapnak a helyi termelök árui, a zöldség és gyümölcs elsősorban a helyi östermelök piacáról kerül az asztalokra. A lakosság nagyrészét megpróbálják rávenni a vegán táplálkozásra, így az állati eredetü élelmiszerek háttérbe szorulnak majd. Várhatóan csökken a különféle divatdiéták követése, inkább az ízletes és kiegyensúlyozott, tápanyagdús és egészséges étrend lesz a követendö. (RUNNER'S 2021)

\section{Roma szokások-hagyományok-táplálkozás összefüggései}

Természetesen a romák életmódja kapcsán is vizsgálni kell a történelmi gyökereket, kultúrát, hagyományokat. Egy olyan etnikumról beszélünk, amelynek jellemzően nincs írásos történelme, így csak a generációk egymásnak átadott információi alapján ismerjük a régi cigányok útját. A cigányságról hazai említést a XIV. századi leírásokban olvashatunk először, vándorló életmódot folytattak egészen addig, amíg Mária-Terézia intézkedései nyomán elkezdődött a letelepedésük a XVIII. században. (Harmatta 1962)

A XIX. század végéig mondhatjuk azt, hogy a cigányság integrálódott a magyar össztársadalomba, majd a századfordulót követően egy dezintegrációkövetkezett be a romák többségénél. 1893-ban országos cigányösszeírást tartottak Magyarországon, amikor 272.776 roma adatát vették fel, de a becslések szerint a valós számuk közel 300 ezer lehetett. Az összeírás alapján a romák 89,2\%-a élt állandó lakhelyen, 7,5\%-a részben letelepedve és csak 3,3\%-ukat minősítették „kóbor cigánynak”. A részben letelepedettek pedig munkájuk miatt vándoroltak időszakosan hasonlóan a parasztokhoz, akik idénymunkákat végeztek a mezőgazdaságban például. Ez az összkép a cigányság nagymértékü integrációját tükrözte a további felemelkedés lehetőségével. Ezidőtájt hazánk lakossága főként mezőgazdaságból élt, a betelepedő romák mégsem parasztként épültek be a társadalomba, melynek alapvető oka a föld hiánya volt. Az itt élő romák jellemzően az iparban (gyepmester és dögnyúzó, favágó, hordár, szénégető, mosás) dolgoztak és nem csupán a férfiak, de a nők többsége is. A foglalkozással nem rendelkező romák az összeírás alapján lopásból, csavargásból, koldulásból, jövendőmondásból vagy a kiutalt segélyekböl éltek. Ez a fajta beintegrálódás 
Kaleidoscope

egészen jól működött az 1960-as évekig, de ekkorra már túlnépesedtek és a rendszer tovább nem tudta biztosítani a megélhetésüket. A letelepedett romák 61,7\%-a házban, 33,3\%-a putriban (,kis nyomorult czigányviskó, melyeknek azonban fala és ablaka is van ...) vagy kunyhóban (földbe süllyesztett „épitmény”), 3,3\%-a pedig sátorban, 1,7\%-a „odúban vagy egyéb helyen” lakott. Ezekből a leírásokból jól látszik, hogy ami nem a klasszikus ház- lakás minőségü volt, abban jellemzően a cigányok laktak, ezek pedig a társadalomtól távolabb álltak, így a romák szegregálódása kialakult. Ettől függetlenül azt mondhatjuk, hogy a 18-19. században a hazai cigányság integrálódott a magyar társadalomba, ha annak csak legalsó rétegeibe is. A kiépített pozícióik azonban a modernizáció miatt meginogtak, csökkent a presztízsük, a legtöbb roma sajnos nem tudta átmenteni pozícióját a modern társadalomba. A 19. század végétől mind nagyobb cigány csoportok dezintegrációja következett be. Megfigyelhetővé vált a társadalmi lemaradás, ennek eredményeként a növekvő mértékü és tartóssá váló munkanélküliség, ami tovább növelte a szegregáció mértékét, ez pedig tovább csökkentette az életszínvonalukat. (DUPCSIK 2015)

1961-ben az önrendelkező cigány közösségek megszünését, a MSZMP KB Politikai Bizottsága 1961. június 20-án kiadta a Cigánylakosság helyzetének megjavitásával kapcsolatos egyes feladatokról címet viselő határozatát (HAJNÁCZKY 2017) követően a cigányság szétszóródott a különböző településeken, így megszünt a szabadon élő roma közösségeknek az a bizonyos belső jogrendje, ami a szokásokon alapuló jog gyakorlata volt. Kötelezővé vált a településhez való tartozás. A cigányok ősi, kulturális hagyományai lényegesen eltérnek az európai népek kulturális szokásaitól. Jellemző rájuk, hogy mindig elszigetelten éltek Európa szerte, ezt a mai napig őrzik, vagyis a társadalom peremén, szegénységben, elöítéletektöl terhesen, vagy teljesen kirekesztve, szegregáltan, sokszor lehetetlen körülmények között éltek/élnek. Ezt a kirekesztettséget egyébként többnyire traumaként élik meg, amiröl még a családon belül a fiatalabb generációknak sem beszélnek szívesen. Ehhez, vagyis tradicionális közösségi léthez kötődve maradtak fent bizonyos rituális szokások, mint a tisztasággal és a beszennyeződéssel kapcsolatos szabályok (márpihe). Ezek azonban nem higiénés normák náluk, hanem sokkal inkább erkölcsiek. Napjainkban azonban már sok roma család él integráltan a befogadó közösségben, így a hagyományos, normatartó cigány közösségek müködését ma már megosztja a lakhatási, a szociális körülmények megléte is.(Örökségünk 2015)

A hagyományok közül azért van, amit a mai napig őriznek, így fontos számukra azok betartása. Ilyen például az idősek és a gyerekek tisztelete, a halottvirrasztás, vagy a cigányzene, a tánc. Persze maradtak fent jellegzetes cigány ételek is, mint a káposzta, a hús, az ezekből készült töltött káposzta, vagy a bodag, vakarcs is. A halott mellé a sírba tesznek az ételeken kívül italt, cigarettát, tárgyakat is, hogy a túlvilágon ne legyen üres kézzel az elhunyt.

A hagyományok örzésén felül meg kell említeni, hogy a romák alkalmazkodó képessége igen nagy, hiszen vándorlásaik során ez tette lehetővé számukra az életben maradást.

\section{Roma étkezés a mindennapokban}

A vándorló életmód lényegesen befolyásolta a táplálkozási szokásaikat is, hiszen attól függött, hogy aznap mit esznek, hogy az asszonyok mire tudták elcserélni a portékáikat, illetve az adott évszakban az úton mit találtak. A cigány családban a gyerek csak 6-7 éves koráig lehet gyerek, utána a fiúk és a lányok már fontos feladatokat kapnak. A lányok is igen korán megtanulják a háztartás vezetését. (Bánlaki 2008) Ez napjainkban is tapasztalható a lokálpatrióta cigány családokban.

A cigányság vándorló életmódjához kötődik, hogy náluk nem alakult ki a rendszeres étkezés. „Akkor eszünk, amikor megéhezünk”, ,fözünk, ha van miböl”, „akkor eszünk, ha elkészül az étel” elvek szerint 
étkeznek. Másrészt a rendszertelen étkezés mellett az egytálételek kapták a fő szerepet, hiszen ezeket volt a legegyszerübb elkészíteni. Az étkezések során az sem volt elhanyagolható szempont, hogy elsőnek mindig a legkisebb gyermekek kaptak ételt. Utánuk a nagyszülök, majd a dédszülők következtek. A sort az étkezésben a családfö követte, utána pedig a nagyobb gyermekek kaptak az ételböl. Végül az anya zárta a sort, a családfőnek volt kötelessége ügyelni arra, hogy az anyának is jusson étel. A cigányság összefogását tükrözte az a szokás is, hogy ha némely családnak aznap nem jutott étel az asztalára, akkor a többiek vagy a tehetősebbek később kisegítették a rászorulókat ennivalóval, de úgy, hogy az ne legyen bántó a családra nézve. (Radics-Farkas 2012:104-108)

A többségi társadalom sokszor adta oda nekik azokat az alapanyagokat, amelyeket ők már nem fogyasztottak volna el, vagy a beteg állatokat, vagy a frissen elhullott állatok tetemét, hiszen a romák elvei szerint semmit sem hagynak kárba veszni (ez az ún. „dögkútról” evés eredete- a hiedelem szerint).

A „dögkútról evés” a cigányokat érintő sztereotípia. Miközben a dögevés valójában nem a cigánysághoz kapcsolódó jelenség, hanem a történelem során több kultúrában, népcsoportban, így a magyarországi népi társadalomban is előfordult. A szükség sok esetben vitte rá az embereket, így nem csak a romákat, az elhullott állatok fogyasztására. (Nagy 2016)

Augustini kutatása szerint a dögevésnek kettős magyarázata van a cigányság körében. Egyrészt kulturális tradíció, másrészt kényszerű túlélési technika. A cigányok úgy tartották, hogy „azoknak az állatoknak a húsa, amelyet Isten pusztított el, jobb kell legyen, mint az ember kezétöl levágott állaté". (Hortis 2009)

A szocializmus idejéből számolnak be kutatások a cigánysághoz kötődő dögkútról való élelem beszerzéséről. A valóságban ekkoriban is a cigányok többsége szegregáltan, telepeken élt igen rossz körülmények között, de ez a mélyszegénység akkoriban tabu volt. A túlélés érdekében az akkori TSZ-ek (Termelő Szövetkezetek) által a cigánytelepek közelében lévő dögkutakra szállították az elhullt állatokat. A frissen, de nem fertőzésben elhullt állatokról azonnal informálták a cigányságot és ők rögtön megkapták a kútnál az állat tetemét, amit a vajda osztott el minden alkalommal az egyes családok között. Egyébként pedig felírták azok nevét, akik ettek a húsból, hogy ha mégis fertőzés ütné fel a fejét, akkor tudják ki érintett a betegségben. (Örszigethy 2013:318-319) Ismereteink szerint legutoljára 1997-ben halt meg egy gyermek Mikekarácsonyfán, mert nem kellő ideig fözték az így szerzett húst. (Kármán 2018:31-32)

A múlt századra visszatekintve a cigányság táplálkozási szokásait a társadalomban elfoglalt helyük határozta meg. Anyagilag, vagy szociálisan három réteget különböztettek meg, amelyek között éles szakadék húzódott. 1) A mélyszegénységben élőkre a rendszertelenség, az ínség ételek (ürge-varjúsündisznó) fogyasztása, az egyoldalú étkezés vagy akár az éhezés volt a jellemzö. 2) A középréteg a paraszti étrendet követte leginkább, ők már kiegyensúlyozottabban táplálkoztak. 3) A jómódúak, a legmódosabbak táplálkozását a ,jó élet”-et kifejezö, szimbolizáló bőséges ételfogyasztás és étrend jellemezte. Ami közös volt mindhárom rétegben, hogy mindannyian hagyománytisztelő ízlésvilággal rendelkeztek.

A szocializmus előtt a mezőgazdaságban jellemzően még nem dolgoztak a cigányok, a vándorlásukhoz kötődő mesterségek termékei adták a megélhetésüket, vagy alkalmi munkaerejüket kínálták a falvak lakóinak és így szerezték be a konyha alapjait. A parasztokkal cserélt élelmiszerek alkották alapvetően az alapanyagokat a fözéshez, mint a liszt, a bab vagy a szalonna. Itt azért érdemes megjegyezni, hogy ezek már olyan gyenge minőségüek voltak, amelyeket a parasztok már nem fogyasztottak el. Rendszert nem találunk a fött és a hideg ételek rendjében, hiszen a vándorló életmód a tartalékolást nem tette lehetővé, csak a frissen cserélt alapanyagokból készítették ételeiket. Így előfordult az is, hogy napjában kétszer is főztek, de volt, hogy csak hideget fogyasztottak. A szegény réteg esetében volt jellemző a beteg vagy a 
Kaleidoscope

frissen elhullott állatok tetemének elfogyasztása is, hiszen ezeket sok esetben odaadták a parasztok a szegény cigányoknak. A nagy ínségben élő romák körében fordult elö, hogy lemásztak a dögkútba élelemért. Közöttük alakult ki a beteg vagy az elhullott állatok boncolásának, feldolgozásának és elkészítésének kifinomult módszere. Pontosan tudták mit kell kidobni és mely részek használhatóak fel fogyasztásra. Ezeket a húsokat aztán ecetes vízben áztatták, hogy a dögszagot elvegyék, majd fedetlen edényben hosszú órákig főzték és végül erős füszerezéssel megsütötték.

Az ezredfordulón már csak ritkán fordult elő, hogy a napszámot terménnyel fizették ki, már a cigányság is csak pénzért vásárolhatott. A szegények között a pénztelenség miatt megjelent a kéregetés, a koldulás. Később emellett már sokan rákényszerültek az új beszerzési módra, ami az élelmiszermaradékok kukázását, gyüjtögetését jelentette. A szegény roma családok napról napra éltek, amikor pénzhez jutottak, akkor jelentősebb mennyiségü élelmiszert vásároltak. Ilyenkor hús is került az asztalra, ami a cigányok esetében még ma is a jólét szimbóluma (miközben a magyar társadalom nagyobb hányadánál a húsfogyasztás már nem a jólét szimbóluma). A szükös anyagi körülmények között élök körében egyértelmü az egyoldalú, zsíros és szénhidrátdús ételek fogyasztása, ahogyan a rendszertelen étkezések is. A hús általában az ünnepi alkalomkor kerülhetett a szegények asztalára. A sikeres, gazdag cigányok bár tagadják a jómód és a táplálkozás szimbolikáját, az étkezésükben egyértelműen tükröződik az összefüggés. Bár a jómódú romáknál már rendszeressé vált az étkezés, de bőségesen kerül mindig étel az asztalra, ennek ellenére azok zsírban és szénhidrátban gazdagok, ami az elhízáshoz vezet. Azonban náluk pont ez a cél, hiszen a kövérség a jómódot jelképezi, az ember értékét leginkább az határozza meg, hogy milyen kövér valaki (Szuhai 1999:94-100) A magyar társadalomban jellemzően a kövérség nem státusz szimbólumként jelenik meg.

\section{Cigány konyha-cigány étel}

A letelepedést követően azonban nyilvánvalóan megváltoztak az ételkészítési lehetőségeik, így változtak a táplálkozási szokásaik is. A romák maguk is vitatkoznak arról, hogy vannak-e „cigány ételek”, avagy inkább cigányosan készült ételekről beszélhetünk. A roma konyhában találhatunk néhány olyan jellegzetes „cigány” ételt, ami a magyar konyhában ismeretlen a vándorló korszakukból, úgymint a cigányragu, ami egy húsos főzelékféle. Hasonló a cigánytúró, ami tulajdonképpen a túróba kevert tojást és lecsót jelenti. A konyhájukban leggyakoribb alapanyagok a káposzta, a bab, a lecsó, a krumpli, és a tejtermékek. Gyakran került az asztalra cigánysaláta, amit minden háztartásban kicsit másként készítettek (fejeskáposzta, répa, zöldpaprika, zöldparadicsom, hagyma). A halászlé, a halpaprikás, a halak készítése inkább a folyók mellett élő cigányok eledele, ezeknek az ételeknek ezért nincs olyan régi hagyományuk, mint a vándorló életmód során készített ételeknek. A húsok közül leginkább a csirkét, a tyúkot, a marhát kedvelték, a sertést kevésbé, hiszen nehezebb volt tartósítani, de a belsőségeket, mint a pacalt is szívesen fogyasztották, vagy a kucura pörköltet, a cigánypecsenyét. Az asszimilálódásnak köszönhetően a roma konyha is lényegesen megváltozott, sok jellegzetes roma ételt elhagytak, míg új recepteket tanultak a befogadó társadalom háziasszonyaitól. Elkezdtek jobb minőségü alapanyagokból főzni. (Bódi 1993:49-56)

Jellegzetes ízvilágot tükröznek a roma ételek, a zöldségfélék fogyasztásának nagy a szerepe az étkezési kultúrájukban. Az időben előrehaladva, az édestészták a közelmúltban jelentek meg a cigány konyha kínálatában. Dominálnak jellemzően a savanyú és az erős ízek. (Radics-Farkas 2012:110) 


\section{Híres cigány emberek és ételeik}

Híres emberek híres cigány ételei, úgymint a Rigó Jancsi, a legényfogó kelkáposztaleves, amelyekhez érdekes történetek is kapcsolódnak.

Rigó János (Pákozd, 1858. -, New York, 1927.), azaz Rigó Jancsi világhírü cigányprímás volt, az életútjáról keveset tudunk, de híres szerelmi története ma is él. A cigány származású zenész igen fiatalon, 15 évesen került majdani apósa zenekarába, ahol a tehetséges fiú a ranglistát végig járva lett híres cigányprímás. Apósa azonban nem nézte jó szemmel sikereit, így a feleségétől való válását követően saját zenekart alapítva már 1896-ban Párizsban játszott az Alhambában. Itt ismerte meg a belga Chimnay herceg nejét, Clara Wardot. A szépséges hercegné rajongott a sármos zenészért és a sűrü találkozások talaján kialakult az Európa szerte híressé vált románc. A prímás megszöktette a hercegnőt, majd annak válását követően összeházasodtak. Nászútjukat a pesti Remy Szállodában (Nemzeti Szálló) töltötték, ahol a szálloda cukrászát megkérte a zenész, hogy készítsen egy olyan különleges desszertet, ami csak a feleségének készül, ezzel kifejezve imádatát neje iránt. Az édességet a következő mondat kíséretében szolgáltatta fel a nejének „Kóstold meg, ez olyan barna, mint a böröm és olyan édes, mint a te szíved”. Az új finomság nem csupán a felesége, de a szálloda, majd az ország kedvence is lett. A híres románc azonban egy évtized múltával véget ért, de a híres cigányprímásról elnevezett sütemény ma is fenntartja a legendát és töretlen sikernek örvend. A tejszínhabos, csokoládés finomság a „cukrászsütemények királynője” napjainkban is minden cukrászda kínálatában megtalálható. (Lázár 2014)

A legényfogó kelkáposztaleves receptje a híres Horváth Pista cigány nótaénekes nevéhez füződik. Az 1980-as években a MTV (Magyar Televízió) „Fözőcske, de okosan” címủ müsorában mutatta be, illetve fözte meg a nótaénekes a receptet a maga stílusában. (C-press 2007)

Ezekből ma is megtalálunk a hazai kínálat palettáján számos ételt.

\section{A modern „romani gastro"}

A hagyományok szerint a cigányok életében igen fontos szerepet kapnak a nagy evések, a közös főzések. A fózés tulajdonképpen a roma nőknél a szeretet kifejezésének eszköze, de ennek tudománya egyben a roma közösségekben a nők megbecsültségét is befolyásolja. Kelendőbb az a nő, aki a konyhában is jártas. Ez ma sincs másként.

A mai modern cigány konyha lényege a kombináció- vagy másképp kreativitás. Ami éppen van otthon, abból kell fözni valami tápláló ételt, hiszen ez az elsődleges szempont. Egyébként ugyanazok az ételek tájegységenként is változnak, a nevük sem mindig ugyanaz, ki mit hoz a családi konyhai hagyományaiból, a szülök, nagyszülök szokásaiból.

\section{Jellegzetes ételek}

tésztafélék: Például a jellegzetes „vakaró”-t ma szabolcsi pizza néven is ismerhetjük, de a „street food” ihlette ,, bodagburger” is készülhet belöle otthon. Manapság is nagy népszerüségnek örvendenek a gyúrt tészták, hiszen kevés alapanyag szükséges az elkészítésükhöz. Az autentikus káposztás vagy tökös lecsót ma is gyakran készítik, de már modern változatban, cukkinivel, vagy padlizsánnal.

húsételek: A szegény, nélkülözésben élő cigány családok asztalára sem régen, sem ma nem került/kerül gyakran pörkölt alapú étel, vagy töltöttkáposzta. Inkább csontos húsból (kacsaszárnytő) vagy belsőségből készült ételek dominálnak a hétköznapokon, hiszen kevés pénzből kell a nagycsaládot jóllakatni. Ezek a puritánabb ételek azonban nem csupán a szegénységet, a nyomort tükrözik, hanem a cigányasszonyok 
Kaleido scope
Journal of History of Culture, Science and Medicine

DOI: $10.17107 / \mathrm{KH} .2021 .22 .109-122$

leleményességét, találékonyságát is. A fözés közben a roma asszonyok sugározzák az életörömöt, ilyenkor zajlanak a nagy beszélgetéseket vagy akár ilyenkor adják át élettapasztalatukat is a fiatalabb generációknak. A romakonyhából sosem kerül ki rossz étel, hiszen azok mindig szeretettel és örömmel készülnek. zöldségek: A modern konyhájukban már gyakrabban megjennek a fözelékfélék is, már nem csak párolt zöldségként elkészítve, hanem akár az ízletes zöldségkrémek variációit is szívesen készítik és fogyasztják. ünnepi étkezések szokásai: Azonban az ünnepi asztal őrzi a hagyományokat ma is, hiszen az ilyenkor roskadásig tele a legkülönfélébb ételek sokaságával. Egyébként ezt a jellegzetességet tekintik ma is a cigányok sajátjuknak, a többségi társadalomhoz képest. A hagyományos keresztény ünnepeken kívül nagy figyelmet kap, mint ünnep 1) a gyermek születése, 2) a lakodalom vagy 3) a halottvirrasztás. A hagyomány, a hiedelem és a babona nem különül el teljesen a cigányoknál, ezeket ma is továbbadják a generációk egymásnak. A hagyományok előtt pedig az ételekkel kell tisztelegni, ma már modern formában, mint pl. a lila liba receptje.

édességek: A vándorló életmód miatt a tradicionális roma konyhában nincsenek sütemények, torták, hiszen ezek elkészítésére nem volt alkalmas az életmód. Ami a régi múltat idézi, de ma is népszerü, az az ún. „mocskos tészta”, amelynek „titka” szerintük ma is a tésztába gyúrt szeretet. Szintén a múltból hozott étel a kalács, amit szinte biztosan az asztalra helyeztek és helyeznek ma is, ez a kelt finomság pedig létezik édes és sós ízben is. A mai roma nők már szívesen sütnek a konyháikban, szívesen kísérleteznek a receptekkel. Nem csupán a gyümölcsös sütemények jelentek meg a palettán, hanem a csokoládé is hódít a sütés világában. A régi roma konyhában a csokoládé teljesen ismeretlen volt. A vendégek fogadásának hagyománya valamelyest már veszített a régi fényéből, de alapvetően ma is tiszteletben tartják a cigány családok.

A vendéget mindig illik bőségesen megkínálni étellel és itallal, ha éppen nincs, akkor a szomszédból is kérnek kölcsön, ugyanakkor a kínálást a vendégnek illik is elfogadnia, mert ha nem, akkor az a bizalmatlanságot jelképezi. (Budai-Tonté 2016)

2019-ben készült interjúk szerint a mai telepeken elö roma fiatal anyáknak nincs idejük egészségtudatosan főzni. Ennek okaként a gyermekkel való foglalkozást említették. Egyébként pedig azt eszik jellemzően, amit éppen megkívánnak. Amikor kerítenek időt, a fözés megtervezésekor igyekeznek figyelembe venni a gyerek vagy a férj kívánságait, de a tápanyag, zsír vagy a vitaminbevitel nem lényeges tényező számukra. (Ember 2019:84-100)

\section{Zárógondolatok}

Összességében azt láthatjuk, hogy a cigány konyha alapjaiban nem tér el lényegesen a magyar konyhától, hiszen az alapanyagok végül is ugyanazok voltak és ma is ugyanabból a kínálatból válogathatunk. Persze akad néhány olyan jellegzetesség is, amit csak a romák tesznek a tányérra, mint pl. a malactartó, de a cigány konyha igazából az, amit a roma asszony a konyhájában süt-föz. Azonban mégis egy kicsit más, mint a többségi társadalom tagjaié. Több színnel, ízzel és lélekkel készülnek az ételek. Talán a vándorló életmódnak köszönhetően a cigányok ételkészítése kicsit több ügyességet, találékonyságot igényel, bátrabban kombinálják a hozzávalókat vagy az ízeket. Megállapítható, hogy a hazai táplálkozást mindig is erőteljesen befolyásolja az adott történelmi időszak, a családok szintjén pedig legnagyobb hatással a társadalmi hovatartozás adta lehetőségek dominálnak. 


\section{Irodalom}

ÁDÁNY R. (2008): A magyar lakosság egészségi állapota, különös tekintettel az ezredforduló utáni időszakra. In: Népegészségügy:86.évfolyam 2. Szám 16.0

ÁDÁNY, R.-SÁNDOR J. (2019): Az északkelet-magyarországi telepszerü körülmények között élő cigány lakosság egészség-magatartása és egészségi állapota. Magyar Tudomány 180(2019)11, 1596-1611 https://doi.org/10.1556/2065.180.2019.11.2

BÁNLAKI, P. (2008): Bölcsőtől a sírig - a cigányok mindennapi kultúrája

BÁTI, A. (2019): Asztali örömök, Érzelmek története. In: Hajnal István Kör Társadalomtörténeti

Egyesület. Budapest pp; 63-77. o

BODI, Zs.(1993): A vándor cigányok táplálkozási szokásai és a változások tendenciái. In: Cigány népi kultúra a Kárpát-medencében a 18-19. században. MNT: Budapest, 1993. pp. 49-56. Bibl. p. 55.

BUDAI, Zs.-TONTÉ, B. (2016): Üljünk egy asztalhoz, Romai gastro, Budapest,7-105

CSÉPE, P. (2010): Hátrányos helyzetű csoportok egészségfelmérése és egészségfejlesztése különös tekintettel a roma populációra. In: Doktori értekezés 96-98

DINNYÉS, K.- PUSZTAFALVI, H.- TARKÓ, K. (2019): A férfiak és nők egészségmagatartásának összefüggése a házastársi, élettársi és elvált családi állapottal. In: Módszertani Közlöny 2019, IX.

évfolyam, 1. szám, 36-63 o.

DUPCSIK, Cs. (2015) A cigányok társadalomtörténete a 19-20. század fordulóján. In: Alapirodalmak a hazai cigány, romanépességre vonatkozó társadalomtörténet, társadalomismeret oktatásához. Pécs: Pécsi Tudományegyetem BTK NKI -Romológia és Nevelésszociológia Tanszék. 295-328

EMBER Zs. (2019), Nyíregyházi, telepi körülmények között élő, 18-29 éves roma fiatalok egészségmagatartása (fókuszcsoportos interjú). In: Acta Medicinae et Sociologica Vol. 10. No. 29. (84100)

HAJNÁCZKY, T. (2017), Az 1961-es párthatározat margójára III. Múltunk 2017/2. 246-247

HARMATTA, J. (1962): The Gipsies in Hungary.In: Gipsies, Publications Division, HORTIS, A. (2009): A magyarországi cigányok mai állapotáról, különös szokásairól és életmódjáról, valamint egyéb tulajdonságairól és körülményeiröl (1775-1776). In: Györffy István Néprajzi Egyesület, Magyar Néprajzi Társaság, Szent István Egyetem, Budapest-Gödöllő http://c-press.hu/20070406213/cigany-etelek/legenyfogo-kelkaposztaleves.html

KÁRMÁN, J. (2018): A magyarországi cigány/ roma népesség kultúrantropológiai és orvosantropógiai megközelítésben. In: Romológiai Füzetek Debrecen, 31-32. o.

KELLER, V.- DERNÓCZY-P. A.- HUSZKA P. (2017): Húsfogyasztási szokások - fókuszban az attitüd. In: Élelmiszer, táplálkozás és marketing XIII. Éve 1/2017;19-24 https://doi.org/10.33567/etm.2254

KISS, A.-ANDÓ R.-FRITZ, P.-LAKNER Z. (2019): Az elhízás jelenlegi és prognosztizált betegségterhe a magyarországi romák körében I. In: Orvosi Hetilap, 2019/ 160. évfolyam, 28. szám, 1097-1104 https://doi.org/10.1556/650.2019.31435

KOCSIS, É.-ANGYAL, M. (2015): Roma gyerekek táplálkozási szokásai. In: Horizontok és dialógusok IV. romológus konferencia tanulmánykötet, Pécs,231-245

KOROKNAY, Zs.- PFAU, C. (2020): Egészséges táplálkozással kapcsolatos szokások egyetemi hallgatók körében. In: Acta Medicinae et Sociologica Vol. 11., Különszám. 18-29

KOZÁK, Á.(2009): Táplálkozás, fogyasztás és életmód a rendszerváltás utáni Magyarországon

Élelmiszer, Táplálkozás És Marketing VI. ÉVF. 1-2/2009;19-23 
Kaleidoscope Mủvelödés-, Tudomány- és Orvostörténeti Folyóirat Journal of History of Culture, Science and Medicine
2021. Vol. 11. No. 22.

ISSN 2062-2597

DOI: $10.17107 /$ KH.2021.22.109-122

LÁZÁR, Zs. (2014). A szerelmetes Rigó Jancsi In: Gasztro, Sztárkonyha (https://cultura.hu/gasztro/aszerelmetes-rigo-jancsi/)

MDOSZ. (2020) Táplálkozsi trendek 2018-ban, In: Táplálkozsi Akadémia, 11.évfolyam, 04.szám

NAGY, P. (2016): Dögevés - Szükség, tabu, sztereotípia. In: Napi történelmi forrás, 2016.12.09

ÖRSZIGETHY, E. (2013): Kum jésty, Bogádmindszent? Iskolapéldák egy észak-ormánsági

körjegyzőségből. In: Szuhay Péter (szerk.): Távolodó világaink. A cigány-magyar együttélés változatai.

Cigány Néprajzi Tanulmányok 16. Magyar Néprajzi Társaság, Bp. 2013. 318-319

PÁSZTOR, I. Z.- PÉNZES J.- TÁTRAI P. (2016): The Number and the Spatial Distribution of the Roma Population in Hungary - In the Light of Different Approaches. In: Folia geographica, Acta facultatis studiorum humanitatis et naturae Universitatis Prešoviensis, FHPV PU Prešov, Prírodné vedy, 58;2 5-21. RADICS, J,- FARKAS, M. (2012): Cigány népismeret, Budapest,104-110.o.

SZUHAI, P. (1999): A magyarországi cigányság kultúrája: etnikus kultúra vagy a szegénység kultúrája, Budapest, $94-100$ o

VAJDA, 1. (2001): Az oláh és beás cigányok szokás- és hiedelemvilágának összehasonlítása. In: Barátság. 8. $2,3147-3150$.

http://old.semmelweis.hu/wp-content/phd/phd_live/vedes/export/csepepeter.d.pdf www.shp.hu/hpc/userfiles/knye/2008_banlaky.doc

A magyar gasztronómia története (2010) https://regi.tankonyvtar.hu/hu/tartalom/tamop412A/20100010_12_Gasztronomia_a_vendeglatasban/2884/index.scorml

http://www.euro.who.int/en/health-topics/noncommunicable diseases/obesity/data-and-statistics https://ec.europa.eu/info/policies/justice-and-fundamental-rights/combatting-discrimination/romaeu/roma-equality-inclusion-and-participation-eu_en\#roma-people-in-the-eu https://www.ogyei.gov.hu/otap_2014

https://www.oronk.hu/2015/08/10/cigany-szokasok/

https://www.who.int/news-room/fact-sheets/detail/obesity-and-overweight https://www.who.int/news-room/fact-sheets/detail/obesity-and-overweight https://nlc.hu/gasztro/20171213/kiderult-hogy-milyen-etkezesi-szokasok-jellemzik-a-magyarokat/ https://www.ksh.hu/docs/hun/xftp/idoszaki/elef/te_2019/index.html

https://www.runnersworld.hu/taplalkozasi-trendek-2021-ben135612-135612

http://www.kaleidoscopehistory.hu

Kocsis Éva doktoranda, Mózes Noémi doktoranda, habil. Feith Helga PhD 